\title{
Comparing The Economy-wide Impact of Omnibus Law: An Input-Output Analysis
}

\author{
Ari Tri Haryanto ${ }^{\text {a* }}$, Budy P. Resosudarmo ${ }^{b}$ \\ ${ }^{a b}$ The Australian National University, ACT, Australia
}

\section{ARTICLE INFORMATION}

\section{Article history:}

Date Submission: 21 January 2021

First Revision: 22 March 2021

Accepted: 26 March 2021

Available Online: 10 April 2021

Keywords: investment, omnibus law, input-output, microsimulation

\section{ABSTRACT}

As the Indonesian government issued Omnibus Law to increase investment inflow to Indonesia, this paper tries to figure out investment in what sector that can generate the highest outcome in terms of the macro, micro, and environmental impacts, such that the Indonesian government should prioritize this sector as the investment targeted sector. Three sectors are considered: manufacturing, mining and quarrying, and electricity and gas. Using an I-O model and a microsimulation model, this paper examines the macro, micro, and environmental impacts of each investment scenario. The results reveal that in the short-run, investment in the electricity and gas sector generates the highest macro impacts, while investment in the mining and quarrying sector is better in reducing poverty and inequality, although it has a bigger environmental impact.

\section{INTISARI}

Mengingat pemerintah Indonesia telah menerbitkan Omnibus Law untuk meningkatkan investasi di Indonesia, penelitian ini bertujuan untuk menginvestigasi mengenai investasi di sektor apa yang dapat menghasilkan dampak terbaik sehingga pemerintah Indonesia harus memprioritaskan sektor tersebut sebagai sektor prioritas investasi. Tiga sektor dipertimbangkan: manufaktur, pertambangan dan penggalian, dan listrik dan gas. Dengan menggunakan model Input-Output dan model mikrosimulasi, penelitian ini meneliti dampak makro, mikro, dan lingkungan atas setiap skenario investasi. Hasil penelitian menunjukkan bahwa dalam jangka pendek, investasi pada sektor listrik dan gas menciptakan dampak makro tertinggi, sementara investasi pada sektor pertambangan dan penggalian lebih baik dalam mengurangi kemiskinan dan ketimpangan, meskipun juga menghasilkan dampat lingkungan yang lebih besar.

\section{Introduction}

In attempt to reach Indonesian vision to be a developed country by 2045 , Indonesia is facing a stagnant economic growth at only around 5 percent for the period 2015-2018 (Coordinating Ministry for Economic Affairs, 2019). This growth rate is not sufficient to help Indonesia to become a developed country by 2045 and to avoid a middle-income trap. It needs at least 5.4-6 percent of growth during 2020-2024 as stated in National Middle- term Development Plan (RPJMN) 2020-2024 (Coordinating Ministry for Economic Affairs, 2019). Investment growth at 6.9-8.1 percent and labor force participation at 68-70 percent are needed as the engine of economic growth (Coordinating Ministry for Economic Affairs, 2019). Thus, some policies need to be taken to attract new investments.

In October 2020, the Indonesian government issued Omnibus Law which the main goal is to enhance ease of doing business by reforming investment rules and taxes 
rules. The Omnibus Law is expected to create a conducive investment environment for local and foreign investors to attract new investments to Indonesia. This raises a question about what sector the Indonesian government needs to prioritize to channel the investment as different sectors have different outcome capacity.

Some argue that investment in the tertiary sector does not create many employments such that the government needs to channel the investment to other sectors that can generate many employments and treat this sector as a priority sector for investment. Suryadarma et al. (2013) explain that "different sectors indeed have different job-creating capacities", such that growth in the different sectors will generate employment differently. They developed a growth-employment model to investigate the sectors most creating jobs in Indonesia for the period 1987 to 2002 . They found that in the urban area, the service sector growth plays an important role in creating urban employment, while in the rural area agriculture sector growth is the main driver of rural employment.

In term of poverty reduction, the different sector also has a different ability to reduce poverty. Loayza and Raddatz (2010, cited in Arias-Vazquez et al., 2012) found that agriculture, construction, and manufacturing sectors' growth generate the fastest poverty reduction. The key in this poverty reduction is that the sectoral growth should be able to easily employ the poor such that they benefit from the sectoral growth (Arias-Vazquez et al., 2012). However, the shreds of evidence about the relationship between sectoral growth and poverty are mixed and depend on the specific context (Arias-Vazquez et al., 2012). Generally, the previous pieces of the literature suggest that the labor-intensive sectors' growth, such as agriculture, construction, and manufacturing mostly benefit the poor, while growth in natural resources could not benefit them (Arias-Vazquez et al., 2012).

For the Indonesian case, Suryahadi et al. (2009) examined the relationship between economic growth and poverty reduction in Indonesia and they found that different sectoral growth contributes differently to poverty reduction. They also found that the urban service sector growth is vital in reducing poverty in the urban area. In addition, it also plays an important role in reducing poverty in rural, while agriculture sector growth in rural comes second. However, industrial sector growth shows a minimum impact on urban and rural poverty reduction. Moreover, a study by González Gordón and Resosudarmo (2019) found that the growth in agriculture sector is more inclusive than manufacturing and services sectors. The GDP growth in agriculture sector increases the expenditure of bottom $20 \%$ of Indonesian household while GDP growth of the manufacturing and services sectors increases income inequality.
The previously mentioned literature uses econometric analysis to measure the impact of sectoral growth on job creation, poverty reduction, and inequality without considering the sectoral interdependency which occurs in the economy. It is reasonable that the growth of a certain sector will induce the growth of other sectors such that increasing demand for one sector will induce an increasing demand for other sectors. Thus, it is important to take the sectoral relationship into account to acquire a complete picture of the role of each sector on the economy. This paper uses an I-O model to examine this sectoral interdependency. This paper will also use a microsimulation model as used by (Yusuf and Resosudarmo (2015) to measure the income distribution impact of each sector considered.

This paper will examine and compare the economywide impacts of the investment in three sectors (primary, tertiary, and secondary sector). This is important for the Indonesian government as the Omnibus Law will attract a significant amount of investment and the Indonesian government should channel this investment to the sector that can yield the highest outcome so that the role of investment in boosting economic growth, generating employment, as well as reducing poverty and inequality can be optimal. Thus, the result of this paper can be a policy recommendation for the Indonesian government in choosing the investment priority sectors.

The rest of the paper is structured as follows. The next section explains the Omnibus Law. It also explains the mindset of the Omnibus Law that shows the relationship between the Omnibus Law and the economy as well as the carbon emission. The third section explains the data and methods for this paper, and the section four explains the simulation scenario used in this paper. Finally, section five shows the result and discussion, and the last section concludes the paper.

\section{Theory}

In October 2020, the Indonesian government passed Law Number 11 Year 2020 about Job Creation which is widely known as Omnibus Law. This law comprises 11 clusters, ranging from a simplification of permits to ease of doing business. However, most of the articles (around 1042 articles) govern the simplification of investment permits. This is because the main goal of this law is to attract investments by lifting the investment barrier. This law is a manifestation of investment deregulation in Indonesia. The deregulation is aimed to create an attractive and conducive environment for investment such that more investment will flow to Indonesia.

The Job Creation law also includes the Tax Provisions and Facilities law that is initially separated from the Job Creation Law. However, the Indonesian government eventually includes the Tax Provisions and 
Facilities law into the Job Creation Law. The Tax Provisions and Facilities law amends 7 laws, namely Income Tax Law, Value Added Tax Law, Tax Provisions Law, Customs Law, Excise Law, Local Taxes and Retribution Law, and Local Government Law.

According to Ministry of Finance (2019b), the Tax Provisions and Facilities law is divided into 6 clusters. The most important cluster is the reduction of the corporate income tax rate. The corporate income tax rate will be reduced from 25 to 22 percent in 2021-2022 and 20 percent in 2023. This corporate income tax rate cut is aimed to make the tax rate more competitive compared to other countries, at least in ASEAN such that it attracts more investment to Indonesia. However, this corporate income tax rate cut eventually is included in Government Regulation in Lieu of Acts Number 1 Year 2020 to provide facilities for companies during the Covid-19 pandemic.

\subsection{Omnibus Law and The Economy}

The Omnibus Law are aimed to be the prime mover of structural change in Indonesia (Coordinating Ministry for Economic Affairs, 2020). This structural change is important in an attempt to reach an average of 6 percent economic growth for bringing Indonesia to become a high-income country in 2045. The Omnibus Law will enable the realization of targeted economic growth by deregulating and harmonizing investment rules to attract more investments.

According to RPJMN 2020-2024, Indonesia needs around Rp36,625.9 - 37,225.8 trillion investment to generate around $5.4-6$ percent of economic growth for the year 2020-2024 (Coordinating Ministry for Economic Affairs, 2019). To attract more investments, Indonesia needs to create a conducive and attractive environment for investment. The Omnibus Law create this environment by increasing the ease of doing business and providing tax incentives. The investment is targeted to grow by 6.6-7 percent to support 6 percent economic growth (Coordinating Ministry for Economic Affairs, 2020). Without the Omnibus Law, the economy will grow by only around 5 percent and it is not sufficient to support the economy grows at 6 percent, the rate Indonesia needed to escape from the middle-income trap.

Figure 1 shows the flow of thought of the Omnibus Law. The Omnibus Law will attract investment to Indonesia which will create new employment opportunities for the Indonesian workforce. The investment is targeted to grow at around 6-7 percent which can create 2.6-3 million new employment opportunities. In turn, the employment will increase the income per capita which in 2024 is targeted at USD $6,000.00$. The increase in the income per capita will eventually increase the purchasing power of households which in turn will increase households' consumption.
These scenarios will finally generate economic growth by 5.7-6 percent.

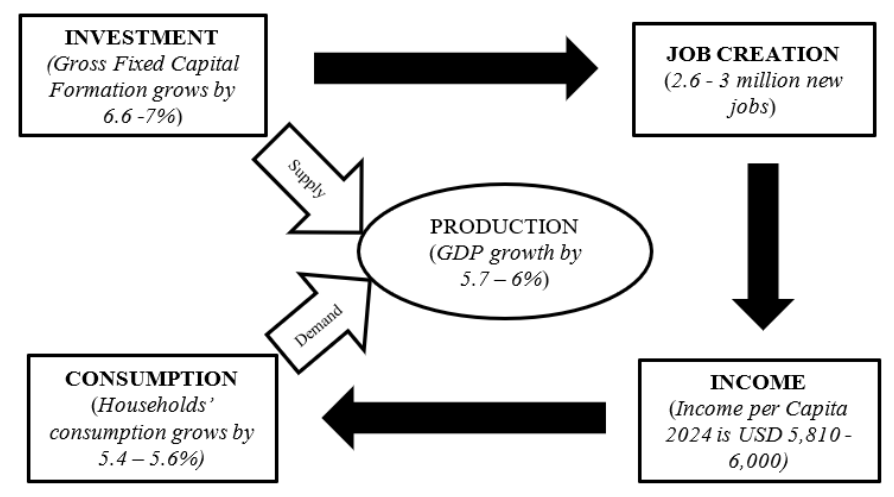

Figure 1 The Mindset of The Omnibus Law Source: Coordinating Ministry for Economic Affairs (2020)

\subsection{Omnibus Law and Carbon Emission}

The increasing investments in many sectors will be inevitably creating some impacts on the environment. The RPJMN 2020-2024 mandates the government to keep the balance between economic growth and the environment, such as lowering the emission level and managing the emission intensity (Coordinating Ministry for Economic Affairs, 2019).

As the Indonesian government joint the 2015 UNFCCC COP 21 in Paris, the government has committed to lowering the carbon emission by 29 percent in 2030. It needs to maintain the carbon emission level under 1,825,374.5 Giga gr CO2/ year and the emission intensity under 261.1 tons CO2/ billion rupiah in 2030 (Coordinating Ministry for Economic Affairs, 2019).

The Omnibus Law will contribute to an increase in carbon emission because the new investments will induce an increase in production activity which in turn generates an increase in carbon emission from the industrial sector. It is important to examine the contribution of the industrial sector in carbon emission increase as the Indonesian government is attempting to lower the carbon emission by 29 percent in 2030. The Indonesian government needs to channel the investment to the sector that creates low carbon emission. The other sources of carbon emission are beyond the scope of this paper.

\section{Research Methods}

\subsection{Data}

To examine the economy-wide impacts of the Omnibus Law, this paper mainly uses the 2010 Indonesian I-O table published by Central Statistics Agency (BPS). The 2010 I-O table comprises 17 sectors based on KBLI (Klasifikasi Baku Lapangan Usaha Indonesia) 2009 which corresponds to International Standard Industrial Classification (ISIC) rev.4. The I-O 
table is used as the main data to examine the macroimpacts of the Omnibus Law. Moreover, to examine the employment inducement impact, this paper uses the number of sectoral workers for the year 2019 published by BPS. Then, to perform microsimulation, this paper uses the National Labor Force Survey (SAKERNAS) 2019 to acquire the individuals' labor income data. For the environmental impacts, this paper uses the 2009 Indonesian air pollution data published by the World Input-Output Database (WIOD).

As there are no investment inflow estimation after the enactment of the Omnibus Law, this paper uses the average investment inflows for the year 2010-2019 published by Investment Coordinating Board as the investment shock. The 2010-2019 period is chosen because it is the period after the 2008 income tax reform was in place, such that it could give a similar pattern of investment inflows to Indonesia. The manufacturing sector is chosen as the benchmark and the average investment inflow for this sector is around 200 trillion rupiahs. This number will be used as an investment shock to examine the economy-wide impacts of Omnibus Law. Then, the estimation of the decrease in tax revenue due to corporate income tax rate cut comes from Fiscal Policy Agency, Ministry of Finance which is available in the academic manuscript of the Tax Provisions and Facilities Bill. The Fiscal Policy Agency estimates that tax revenue will decrease by 53.035 trillion rupiahs if the corporate income tax rate is cut from 25 percent to 22 percent. This estimation will be used as the government spending shock.

Table 1 Investment Coefficient Matrix

\begin{tabular}{|c|c|c|c|}
\hline Sector & Manufacturing & $\begin{array}{c}\text { Mining } \\
\text { and } \\
\text { Quarrying }\end{array}$ & $\begin{array}{c}\text { Electricity } \\
\text { and Gas }\end{array}$ \\
\hline Manufacturing & $42.47 \%$ & $46.94 \%$ & $21.80 \%$ \\
\hline Construction & $52.46 \%$ & $47.84 \%$ & $73.81 \%$ \\
\hline $\begin{array}{l}\text { Wholesale and } \\
\text { Retail Trade }\end{array}$ & $3.51 \%$ & $3.62 \%$ & $3.04 \%$ \\
\hline $\begin{array}{l}\text { Transportation } \\
\text { and Storage }\end{array}$ & $0.88 \%$ & $0.91 \%$ & $0.76 \%$ \\
\hline Other Services & $0.68 \%$ & $0.70 \%$ & $0.58 \%$ \\
\hline Total & $100 \%$ & $100 \%$ & $100 \%$ \\
\hline
\end{tabular}

Source: Lewis (1991), Resosudarmo (2008)

Note: The figure for manufacturing is an average of industries within the manufacturing sector

To examine the impacts of investment inflow, the additional investment is treated as the addition of final demand in the I-O table, particularly an addition in Gross Fixed Capital Formation (GFCF). This paper follows the investment coefficient matrix by Lewis (1991) as shown in Table 1 to distribute the additional investment in the IO table.

\subsection{Methods}

\subsubsection{I-O Model}

This paper uses an open Leontief I-O model to examine macro and environmental impacts. First, it needs

$\mathrm{A}=\left[\begin{array}{cccc}a_{11} & a_{12} & \ldots & a_{1 n} \\ a_{21} & a_{22} & \cdots & a_{2 n} \\ \cdots & \cdots & \cdots & \cdots \\ a_{n 1} & a_{n 2} & \cdots & a_{n n}\end{array}\right] \quad$ where $a_{i j}=\frac{x_{i j}}{x_{j}}$

to calculate the Leontief Matrix (multiplier matrix). The Leontief Matrix is defined as (I-A)-1 in which I is an identity matrix and A is the input coefficient matrix (Jun et al., 2018), as shown by equation (1).

After calculating the Leontief Matrix, the macro impact (output, value-added, and employment inducement impacts) and environmental impact (air pollution inducement impacts) can be calculated.

$$
\begin{aligned}
& \Delta X=(I-A)^{-1} \Delta F \\
& \Delta V=\hat{V}(I-A)^{-1} \Delta F \\
& \Delta L=\hat{L}(I-A)^{-1} \Delta F \\
& \Delta P=\hat{P}(I-A)^{-1} \Delta F
\end{aligned}
$$

In equation (2), $X$ denotes the total output and $F$ denotes the exogenous final demands. The value-added inducement impact $(V)$ is shown by equation (3) where $\widehat{V}$ denotes a diagonal matrix of the value-added coefficient $\left(V_{j} / X_{j}\right)$. Moreover, equation (4) shows the employment inducement impact where $\hat{L}$ denotes the diagonal matrix of the employment coefficient $\left(L_{j} / X_{j}\right)$. The air pollution inducement impact is shown by equation (5) where $\hat{P}$ denotes the diagonal matrix of the air pollution intensity coefficient $\left(P_{j} / X_{j}\right)$.

\subsubsection{Microsimulation Model}

To examine the micro-impact of Omnibus Law, this paper follows Nurdianto and Resosudarmo (2016) to perform a microsimulation model. This model connects the I-O model with the individual labor income data which comes from SAKERNAS 2019. Initially, the survey data are divided into urban and rural individuals, and then they are divided further into 100 groups according to their labor income level. Thus, there are 100 percentiles of individuals in both urban and rural. For each percentile, the number of workers in each sector (17 sectors as in the survey) is calculated to find the proportion to the total workers of each sector. The mathematical equation for the microsimulation model is as follows.

$L I_{i}=\delta_{i}\left[\Sigma\left(L_{i, j} / T L_{j}\right) X_{j}\right]$

Where:

$i$ : percentile (1-100)

$j \quad$ : number of sectors (17 sectors)

$L I_{i}:$ labor income for percentile $i$ 
$\delta_{i}:$ scaling factor of labor incomes to I-O table for percentile $i$

$L_{i, j} \quad$ : number of labors in sector $j$ for percentile $i$

$T L_{j}:$ total labors in sector $j$

$X_{j} \quad$ : total output sector $j$ (from I-O table)

In equation (6), the labor income of each percentile

is a function of the proportion of sectoral workers and the output of that sector. The proportion of sectoral workers is assumed to remain constant and only change in the sectoral output that will change the labor income. The constant parameter $\delta_{i}$ is used to equalize the labor income with the sectoral output.

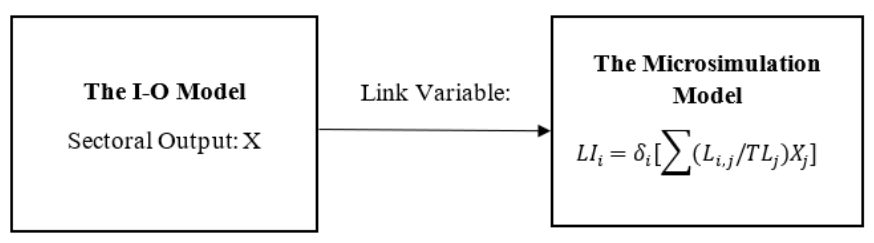

Figure 2 Link Between the I-O Model and The Microsimulation Model

Source: Analyzed from Resosudarmo (2020)

As shown in Figure 2, the sectoral output $X$ from the I-O model plays as a link variable that connects the I-O model and the microsimulation model. The parameter $\delta$ should be calculated first, using the labor income data, the sectoral output from the I-O table, and the proportion of workers in each sector. Once the shocks are applied to the I-O model and output of each sector changes, the right-hand side of equation (6) will also change except for $\delta$ that is kept constant. Given the constant value of $\delta$, the labor income will also change. This microsimulation model enables the examination of change in labor income distribution caused by the change in output due to the shock considered in this paper.

This paper will use the microsimulation result to calculate the Gini coefficient and the poverty incidence in Indonesia. However, the Gini coefficient and poverty incidence are limited only to labor income and do not include non-labor income. Although this limitation, the change in the labor-income-based Gini coefficient and poverty incidence are worth to consider. The calculation of poverty incidence follows the study by Yusuf and Resosudarmo (2015). This paper employs March 2019 Indonesian poverty line set by BPS to determine the poverty incidence. The poverty line for urban is IDR 442,063 per month while rural is IDR 404,398 per month.

\subsection{Simulation Scenarios}

In the I-O analysis, any change (shock) in the final demand will change the total output. This paper considers three shocks that will occur as a result of the enactment of the Omnibus Law. The first one is a 200 trillion rupiah of additional investment inflows. This number is the average investment inflows to the manufacturing sector for the period 2010-2019 as this was the period after the enactment of the 2008 tax reform such that it might help to provide a similar pattern of investment inflows. The manufacturing sector is chosen because it is the main contributor to the Indonesian GDP for around 20 percent (Ministry of Industry, 2019).

The second shock is the decrease in government tax revenue. It is estimated that there will be a 50.035 trillion rupiah of tax revenue decrease due to corporate income tax rate cut from 25 percent to 22 percent (Fiscal Policy Agency, 2019, cited in Ministry of Finance, 2019a). This paper uses the same approach by Amir et al. (2013) in that government balance budget assumption holds. Based on this assumption, a decrease in corporate income tax rate leads to a decrease in government tax revenue which in turn decreases government expenditure because the government needs to keep the budget neutrality position (Amir et al., 2013). Thus, a 50.035 trillion rupiah decrease in tax revenue will be translated into the decrease in government expenditure. In the I-O table, this will be translated into a decrease in the final demand in the government consumption section. The decrease in government consumption will be shared proportionally to each sector.

Furthermore, as a decrease in tax revenue means an addition to corporate revenue and given the fact that in the I-O model household is the owner of capital and labor, a decrease in tax revenue will eventually increase household income. An increase in household income will then increase household consumption. In the I-O model, it will be shown as the increase of final demand in the household consumption section. This increase will also be shared proportionally. Hence, this second shock constitutes a re-allocation of a 50.035 trillion rupiah of government consumption decrease to become a household consumption increase.

The last shock is an increase in return on capital. This paper assumes a 5 percent increase in the return on capital. This increase happens because an increase in investment will increase firms' technical efficiency and productivity which in turn increases firms' performance and profit (Arnold \& Javorcik, 2009; Suyanto et al., 2014; Lee et al., 2015). The 5 percent increase in the return on capital will be translated into an increase in the business surplus coefficient in the I-O model.

These shocks will be simulated into three different scenarios. In the first scenario (SIM 1), the shocks are simulated to the manufacturing sector while in the second scenario (SIM 2) they are simulated to the mining and quarrying sector. The last scenario (SIM 3) is the simulation of the shocks to the electricity and gas sector. These scenarios enable a comparison of the economywide impacts of Omnibus Law to answer the question about investment in what sector that can generate the highest outcome. 


\section{Results and Discussion}

\subsection{Macro and Environmental Impacts}

Table 2 shows the macro and environmental impacts in the short run. In Table 2, it is shown that the total output will increase by around $2.22-2.87$ percent, with the biggest increase, is in SIM 3, while the smallest increase is in SIM 1. For the value-added impact, the result is also the same that SIM 3 creates the biggest impact by 2.40 percent increase and SIM 1 creates the smallest increase by only 1.73 percent. Similarly, SIM 3 also creates the biggest employment impact by 2.01 percent increase and SIM 1 generates the lowest impact by 1.29 percent. Overall, in terms of macro impacts, SIM 3 generates the biggest impact while SIM 1 generates the lowest impact.

Moreover, Table 2 also shows the environmental impacts of the three simulations. SIM 1 generates the smallest additional change of air pollution emission while SIM 2 generates the highest additional change of air pollution emission. SIM 1 increases $\mathrm{CO} 2$ emission by 2.11 percent which is equal to $6,998.65$ Giga gram $\mathrm{CO} 2 /$ year, while SIM 2 increases 2.58 percent of $\mathrm{CO} 2$ emission which is equal to 8,559.37 Giga gram CO2/year. Overall, Table 4 shows that investment in the electricity and gas sector (SIM 3) generates the biggest increase in total output, value-added, and employment, while investment in the mining and quarrying sector (SIM 2) creates the highest change in air pollution emission.

Table 2 Macro and Environmental Impacts (in percentage change)

\begin{tabular}{|c|c|c|c|}
\hline & SIM 1 & SIM 2 & SIM 3 \\
\hline \multicolumn{4}{|l|}{ Macro Impacts: } \\
\hline Output & 2.22 & 2.52 & 2.87 \\
\hline Value Added & 1.73 & 2.06 & 2.40 \\
\hline Employment & 1.29 & 1.88 & 2.01 \\
\hline \multicolumn{4}{|l|}{$\begin{array}{l}\text { Environmental } \\
\text { Impacts: }\end{array}$} \\
\hline $\mathrm{CO}_{2}$ & 2.11 & 2.58 & 2.37 \\
\hline $\mathrm{CH}_{4}$ & 1.50 & 2.33 & 2.33 \\
\hline $\mathrm{N}_{2} \mathrm{O}$ & 1.21 & 2.69 & 2.39 \\
\hline
\end{tabular}

Source: analysis result, 2020

A further examination on the macro impacts as shown by Figure 3 reveals that construction sector (sector 6 ) is the winner for all simulations while public administration sector (sector 14) is the loser with the biggest decrease in the output, followed by education sector (sector 15) and health and social work sector (sector 16) which also experience a negative impact. Furthermore, the figures for the sectoral value-added and employment impacts show the same results as valueadded and employment are determined by the total output.

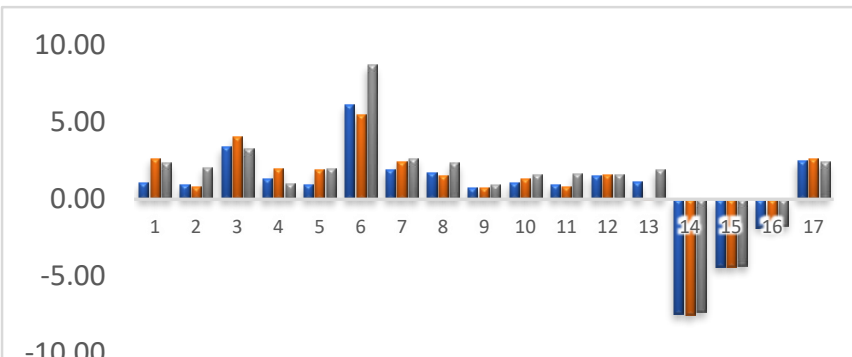

$\square \operatorname{SIM} 1 \square \operatorname{SIM} 2 \square \operatorname{SIM} 3$

Figure 3 Sectoral Output Change (in percentage) Source: Analysis result, 2020

\subsection{Micro Impacts}

Figure 4 shows the change in labor income generated by each simulation. In Figure 4, the $\mathrm{x}$-axis represents the ranked individual from the poorest to the richest, while the $y$-axis represents the percentage change of labor income. All simulations generate a positive increase in labor income for each percentile of individuals.

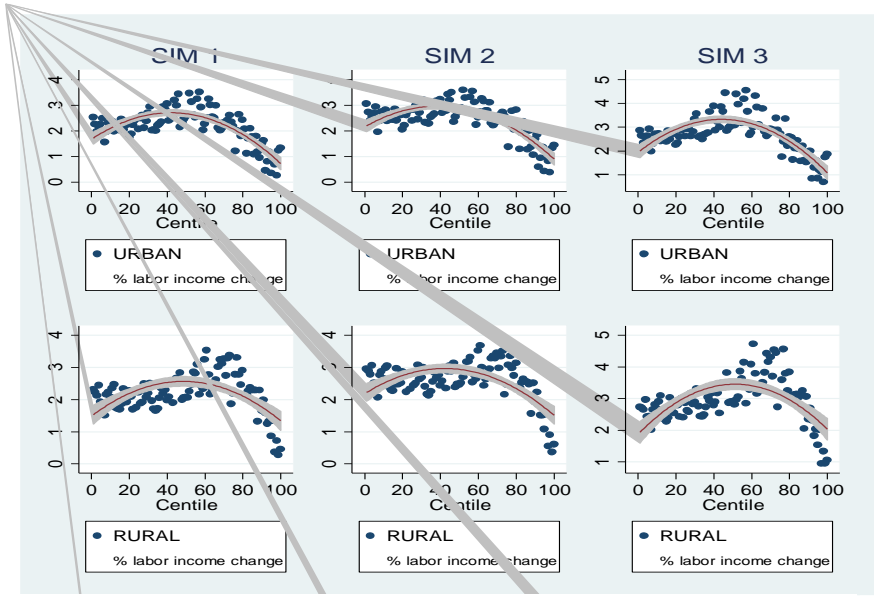

Figure 4 The Impact of Investment on Labor Income

Source: Analysis result, 2020

However, the middle-income level experiences the biggest change in labor income with the bottom 20 percent comes second. The top 20 percent of individuals experience the least increase. This condition will shape a new income distribution in both urban and rural. If the middle-income individuals are excluded, this distribution of economic gain is regressive as the top 20 percent earners experience less change than the bottom 20 percent. Thus, income inequality as well as poverty will change after this distribution of income. Table 3 shows the microsimulation results of poverty incidence and the Gini coefficient in detail.

As shown in Table 3, SIM 2 and SIM 3 generate the biggest decrease in poverty incidence for urban and rural by -0.21 and -0.45 percent, respectively, while SIM 1 creates the smallest effect on poverty incidence compared to the other simulations. Moreover, all simulations are 
also able to decrease the Gini coefficient, suggesting that labor income inequality decreases. SIM 2 generates the biggest decrease in the Gini coefficient for both urban and rural with -0.0031 and -0.0026 , respectively. Overall, in terms of combatting poverty and inequality, SIM 2 performs the best among other simulations.

Table 3 Change in Poverty Incidence and Gini Coefficient

\begin{tabular}{|c|c|c|c|}
\hline & SIM 1 & $\operatorname{SIM} 2$ & SIM 3 \\
\hline \multicolumn{4}{|l|}{ Poverty Incidence: } \\
\hline \multicolumn{4}{|l|}{ Urban } \\
\hline Ex-ante (\%) & 5.83 & 5.83 & 5.83 \\
\hline Ex-post (\%) & 5.65 & 5.62 & 5.62 \\
\hline Change (\%) & -0.18 & -0.21 & -0.21 \\
\hline \multicolumn{4}{|l|}{ Rural } \\
\hline Ex-ante $(\%)$ & 10.23 & 10.23 & 10.23 \\
\hline Ex-post (\%) & 9.86 & 9.77 & 9.77 \\
\hline Change (\%) & -0.37 & -0.45 & -0.45 \\
\hline \multicolumn{4}{|l|}{ Gini Coefficient: } \\
\hline \multicolumn{4}{|l|}{ Urban } \\
\hline Ex-ante & 0.4203 & 0.4203 & 0.4203 \\
\hline Ex-post & 0.4175 & 0.4172 & 0.4173 \\
\hline Change & -0.0028 & -0.0031 & -0.0029 \\
\hline \multicolumn{4}{|l|}{ Rural } \\
\hline Ex-ante & 0.4236 & 0.4236 & 0.4236 \\
\hline Ex-post & 0.4215 & 0.4210 & 0.4215 \\
\hline Change & -0.0021 & -0.0026 & -0.0021 \\
\hline
\end{tabular}

Source: analysis result, 2020

Furthermore, it is also important to know the interindustry relationship among the sectors such that it is possible to examine how an increase in the output of one sector affects the output of other sectors that in turn change the income distribution in those sectors. The I-O model provides the method to further analyze the sectoral linkage. Following Miller \& Blair (2009), the Leontief multiplier matrix can be written as

$(I-A)^{-1}=\left(I+A+A^{2}+A^{3}+\cdots\right)$

such that equation (2) can be rewritten as

$\Delta X=\left(I+A+A^{2}+A^{3}+\cdots\right) \Delta F$

Equation (8) enables the round-by-round analysis to examine the contribution of demand of each sector on the output generation of other sectors.

In the simulation scenarios of this paper, the construction sector receives the majority of the investment fund such that it is important to examine the relationship between the construction sector and the other sectors. In the production process, to satisfy the demand of the construction sector, it needs intermediate inputs from various sectors, such as the manufacturing sector. Then, the manufacturing sector also needs intermediate inputs from other sectors, such as the agriculture sector. Thus, the increasing demand for the construction sector will not only increase the production of the construction sector itself but also triggers the production of other sectors, such as the manufacturing and agriculture sectors.

Table 4 Round-by-Round Analysis (in percentage)

\begin{tabular}{|c|c|c|c|c|}
\hline Sector & $\begin{array}{l}\text { Manufac } \\
\text { turing }\end{array}$ & $\begin{array}{l}\text { Constru } \\
\text { ction }\end{array}$ & $\begin{array}{l}\text { Wholesale and } \\
\text { Retail Trade }\end{array}$ & $\begin{array}{c}\text { Transpor } \\
\text { tation } \\
\text { and } \\
\text { Storage }\end{array}$ \\
\hline $\begin{array}{l}\text { Agriculture, } \\
\text { Forestry and } \\
\text { Fishery } \\
\end{array}$ & 55.56 & 18.82 & 2.95 & 1.69 \\
\hline $\begin{array}{l}\text { Mining and } \\
\text { Quarrying }\end{array}$ & 49.31 & 26.35 & 3.12 & 1.55 \\
\hline Manufacturing & 30.83 & 36.47 & 6.91 & 3.96 \\
\hline $\begin{array}{l}\text { Electricity and } \\
\text { Gas }\end{array}$ & 26.63 & 12.02 & 10.57 & 2.24 \\
\hline $\begin{array}{l}\text { Water Supply, } \\
\text { Waste } \\
\text { Management, } \\
\text { and Recycling }\end{array}$ & 45.71 & 16.77 & 11.26 & 2.68 \\
\hline Construction & 18.93 & 15.99 & 14.31 & 4.53 \\
\hline $\begin{array}{l}\text { Wholesale and } \\
\text { Retail Trade }\end{array}$ & 34.40 & 33.49 & 5.60 & 3.73 \\
\hline $\begin{array}{l}\text { Transportation } \\
\text { and Storage }\end{array}$ & 23.00 & 31.61 & 11.71 & 8.59 \\
\hline $\begin{array}{l}\text { Hotel and } \\
\text { Restaurant }\end{array}$ & 14.54 & 24.62 & 8.76 & 4.00 \\
\hline $\begin{array}{l}\text { Information and } \\
\text { Communication }\end{array}$ & 22.71 & 16.83 & 12.21 & 3.97 \\
\hline $\begin{array}{l}\text { Finance and } \\
\text { Insurance }\end{array}$ & 24.04 & 18.51 & 18.81 & 3.93 \\
\hline Real Estate & 16.08 & 16.47 & 44.58 & 2.59 \\
\hline $\begin{array}{l}\text { Company } \\
\text { Services }\end{array}$ & 22.89 & 23.82 & 12.67 & 7.03 \\
\hline $\begin{array}{l}\text { Public } \\
\text { Administration, } \\
\text { Defense, and } \\
\text { Compulsory } \\
\text { Social Security }\end{array}$ & 20.35 & 27.51 & 4.75 & 4.68 \\
\hline Education & 7.35 & 10.34 & 6.44 & 1.67 \\
\hline $\begin{array}{l}\text { Health and } \\
\text { Social Work }\end{array}$ & 14.62 & 13.48 & 6.43 & 2.14 \\
\hline Other Services & 7.37 & 6.49 & 2.94 & 0.96 \\
\hline
\end{tabular}

Source: analysis result, 2020

As shown in Table 4, the construction sector demand contributes to 36.47 percent of the additional output generation of the manufacturing sector. Moreover, the manufacturing sector demand contributes to 55.56 percent of additional output generation of the agriculture sector. This helps to explain that although there is no direct investment allocated to the agriculture sector in all simulation scenarios, the demand in the agriculture sector increases quite significantly due to the increasing demand for other sectors, resulting in a decrease in poverty incidence and inequality. It also sheds light that to 
increase the output of the agriculture sector, it does not necessarily have to increase the investment in the agriculture sector itself, but it can be done through the investment increase in other sectors because there is a sectoral linkage among the sectors. In this case, the manufacturing sector demand plays an important role in generating the production of agriculture sector output.

\subsection{Sensitivity Analysis}

To check the robustness of the simulation results, this paper conducts sensitivity analysis by changing the increase in return on capital assumption. This assumption will be loosened by around 5 percent. At first, the increase in return on capital will be assumed to be zero while in the second one, the increase in return on capital will be increased to 10 percent. Each of these assumptions, along with the other shocks, will be simulated to the manufacturing sector, mining and quarrying sector, and electricity and gas sector. Then, the simulation results are combined with SIM 1, SIM 2, and SIM 3, and the average of each result is taken. Tables 5 and 6 show the average macro, environmental, and micro impacts.

Table 5 Average Macro and Environmental Impacts (percentage change)

\begin{tabular}{lccc}
\hline & \multicolumn{3}{c}{ Investment Sector } \\
\cline { 2 - 3 } & Manufacturing & $\begin{array}{c}\text { Mining } \\
\text { and } \\
\text { Quarrying }\end{array}$ & $\begin{array}{c}\text { Electricity } \\
\text { and Gas }\end{array}$ \\
\cline { 2 - 3 } $\begin{array}{l}\text { Macro Impacts: } \\
\text { Output }\end{array}$ & 2.22 & 2.52 & 2.87 \\
Value Added & 1.73 & 2.06 & 2.40 \\
Employment & 1.29 & 1.88 & 2.01 \\
Environmental & & & 2.37 \\
Impacts: & 2.12 & 2.59 & 2.33 \\
$\mathrm{CO}_{2}$ & 1.51 & 2.33 & 2.39 \\
$\mathrm{CH}_{4}$ & 1.21 & 2.69 & \\
$\mathrm{~N}_{2} \mathrm{O}$ & 2020 & &
\end{tabular}

Source: analysis result, 2020

Table 5 shows that, on average, an investment in the electricity and gas sector generates the highest increase in output, value-added, and employment, while in terms of air pollution, an investment in the mining and quarrying sector generates the highest air pollutions increase. These results are consistent with the previous simulations that SIM 3 generates the highest macro impacts, while SIM 2 generates the highest air pollution impacts. Moreover, as shown in Table 6 , investment in the mining and quarrying sector seems to be better in tackling poverty and inequality than investment in the manufacturing sector and electricity and gas sector. This result is also consistent with the previous simulations in that SIM 2 reduce poverty incidence and inequality better than the other simulations.
Table 6 Average Change in Poverty Incidence and Gini Coefficient

\begin{tabular}{|c|c|c|c|}
\hline \multirow[b]{3}{*}{$\begin{array}{l}\text { Poverty } \\
\text { Incidence: }\end{array}$} & \multicolumn{3}{|c|}{ Investment Sector } \\
\hline & Manufacturing & $\begin{array}{c}\text { Mining } \\
\text { and } \\
\text { Quarrying }\end{array}$ & $\begin{array}{c}\text { Electricity } \\
\text { and Gas }\end{array}$ \\
\hline & & & \\
\hline \multicolumn{4}{|l|}{ Urban } \\
\hline Ex-ante $(\%)$ & 5.83 & 5.83 & 5.83 \\
\hline Ex-post (\%) & 5.65 & 5.62 & 5.62 \\
\hline Change (\%) & -0.18 & -0.21 & -0.21 \\
\hline \multicolumn{4}{|l|}{ Rural } \\
\hline Ex-ante $(\%)$ & 10.23 & 10.23 & 10.23 \\
\hline Ex-post (\%) & 9.86 & 9.77 & 9.77 \\
\hline Change (\%) & -0.37 & -0.46 & -0.46 \\
\hline \multicolumn{4}{|l|}{ Gini Coefficient: } \\
\hline \multicolumn{4}{|l|}{ Urban } \\
\hline Ex-ante & 0.4203 & 0.4203 & 0.4203 \\
\hline Ex-post & 0.4175 & 0.4172 & 0.4173 \\
\hline Change & -0.0028 & -0.0031 & -0.0030 \\
\hline \multicolumn{4}{|l|}{ Rural } \\
\hline Ex-ante & 0.4236 & 0.4236 & 0.4236 \\
\hline Ex-post & 0.4215 & 0.4210 & 0.4215 \\
\hline Change & -0.0021 & -0.0026 & -0.0021 \\
\hline
\end{tabular}

Source: analysis result, 2020

\section{Conclusion}

This paper aims to answer the question about investment in what sector that can generate the highest outcome. According to the three simulation scenarios, SIM 3 generates the highest macro impacts while SIM 2 performs better in reducing poverty and inequality than SIM 3. However, SIM 2 generates the highest increase in air pollution emission compared to other simulation scenarios. Given these results, Indonesian government can choose to channel the investment to electricity and gas sector if it considers the macro impact and environmental impacts more, but if it considers poverty and inequality reduction more, it can choose the mining and quarrying sector as an investment priority sector, with the expense of having bigger air pollution emission increase from industrial sectors.

Furthermore, this paper also finds that the agriculture, manufacturing, and wholesale and retail trade sectors growth plays an important role in reducing poverty and inequality as most of the bottom 20 percent earners work in these sectors. Investment in any sector that can induce significant growth in these sectors will reduce poverty and inequality significantly. The roundby-round analysis suggests that the construction sector plays a big role in inducing demand for the manufacturing 
sector, while the manufacturing sector plays a significant role in inducing demand for the agriculture sector. Considering that most of the poor work in the agriculture sector, additional investment in the construction and manufacturing sectors can be an option as it significantly induces an increase in the output of the agriculture sector which eventually benefits most of the bottom 20 percent earners work in this sector.

This paper uses the I-O model to simulate the economy-wide impacts of Omnibus Law. The I-O model only enables a short-term prediction of the shocks to the economy. The long-term impacts cannot be captures by this model. Thus, the simulation results in this paper are only for the short-term impacts and the long-term impacts could be different from these results.

Furthermore, this paper uses the 2010 Indonesian I$\mathrm{O}$ table as the core data so that it is assumed that the economic pattern in Indonesia does not change until 2019. In addition, the inherent drawbacks of the I-O model are also implied in this paper, such as it does not take into account the price and quantity changes. Future research should tackle these drawbacks.

\section{References}

Amir, H., Asafu-Adjaye, J., \& Ducpham, T. (2013). The impact of the Indonesian income tax reform: A CGE analysis. Economic Modelling, 31, 492-501. http://dx.doi.org/10.1016/j.econmod.2012.12.018

Arias-Vazquez, F. J., Lee, J. N., \& Newhouse, D. (2012). The Role of Sectoral Growth Patterns in Labor Market Development. Bonn, Germany: The Institute for the Study of Labor (IZA). https://doi.org/10.1596/1813-9450-6250

Arnold, J. M., \& Javorcik, B. S. (2009). Gifted kids or pushy parents? Foreign direct investment and plant productivity in Indonesia. Journal of International Economics, 79, 42-53. https://doi.org/10.1016/j.jinteco.2009.05.004

Coordinating Ministry for Economic Affairs. (2019). Rencana pembangunan jangka menengah nasional 2020-2024. Coordinating Ministry for Economic Affairs.

Coordinating Ministry for Economic Affairs. (2020, December 2). Penjelasan rancangan undangundang cipta kerja.

Duhaime's Law Dictionary. (n.d.). Omnibus Bill Definition. Retrieved June 11, 2020, from http://www.duhaime.org/LegalDictionary/O/Omn ibusBill.aspx

González Gordón, I., \& Resosudarmo, B. P. (2019). A sectoral growth-income inequality nexus in Indonesia. Regional Science Policy \& Practice, 11(1), 123-139. https://doi.org/10.1111/rsp3.12125
Jun, W. K., Lee, M.-K., \& Choi, J. Y. (2018). Impact of the smart port industry on the Korean national economy using input-output analysis. Transportation Research Part A, 118, 480-493. https://doi.org/10.1016/j.tra.2018.10.004

Lee, D., Rho, B.-H., \& Yoon, S. (2015). Effect of investments in manufacturing practices on process efficiency and organizational performance. Int. J. Production Economics, 162, 45-54. http://dx.doi.org/10.1016/j.ijpe.2015.01.001

Lewis, J. D. (1991). A computable general equilibrium (CGE) model of Indonesia. Harvard Institute for International Development Series of Development Discussion Papers No. 378. Cambridge, MA: Harvard Institute of International Development.

Miller, R. E., \& Blair, P. D. (2009). Input-output analysis: Foundation and extensions (Second Edition). New York: Cambridge University Press.

Ministry of Finance of the Republic of Indonesia. (2019a). Rancangan undang-undang tentang ketentuan dan fasilitas perpajakan untuk penguatan perekonomian. Ministry of Finance of the Republic of Indonesia.

Ministry of Finance of the Republic of Indonesia. (2019b). Ini 6 Cluster Omnibus Law Perpajakan yang Dibahas dalam Prolegnas. Accessed on June, 12, 2020, retrieved from https://www.kemenkeu.go.id/publikasi/berita/ini6-cluster-omnibus-law-perpajakan-yang-dibahasdalam-prolegnas/

Ministry of Industry of the Republic of Indonesia. (2019). Kemenperin: Kontribusi manufaktur nasional capai 20 persen, RI duduki posisi ke-5 dunia. Accessed on June, 12, 2020, retrieved from https://kemenperin.go.id/artikel/20579/Kontribusi -Manufaktur-Nasional-Capai-20-Persen,-RIDuduki-Posisi-Ke-5-Dunia

Nurdianto, D. A., \& Resosudarmo, B. P. (2016). The economy-wide impact of a uniform carbon tax in ASEAN. Journal of Southeast Asian Economies, 33(1), 1-21. https://doi.org/10.1355/ae33-1a

Resosudarmo, B.P. (2008). The Economy-wide Impact of Integrated Pest Management in Indonesia. ASEAN Economic Bulletin, 25 (3), 316-333.

Resosudarmo, B.P. (2020). Modeling impact of economy wide policies on income distribution and poverty. Lecture slides. IDEC8031. Semester 1 2020. ANU: Canberra.

Suryadarma, D., Suryahadi, A., \& Sumarto, S. (2013). Sectoral growth and job creation: Evidence from Indonesia. Journal of International Development, 25 (4), 549-561. https://doi.org/10.1002/jid.1763

Suryahadi, A., Suryadarma, D., \& Sumarto, S. (2009). The effects of location and sectoral components of economic growth on poverty: Evidence from 
Indonesia. Journal of Development Economics, 89(1), $109-117$. https://doi.org/10.1016/j.jdeveco.2008.08.003

Suyanto, Salim, R., \& Bloch, H. (2014). Which firms benefit from foreign direct investment? Empirical evidence from Indonesian manufacturing. Journal of Asian Economics, 33, 16-29. http://dx.doi.org/10.1016/j.asieco.2014.05.003

Tax Updates. (2019). Omnibus law rancangan undangundang ketentuan dan fasilitas perpajakan. pbTaxand, 10.

Yusuf, A. A., \& Resosudarmo, B. P. (2015). On the distributional impact of a carbon tax in developing countries: The case of Indonesia. Environmental Economics and Policy Studies, 17 (1), 131-156. https://doi.org/10.1007/s10018-014-0093-y 